\title{
INSECTICIDAL EVALUATION OF AQUEOUS EXTRACT OF INDIGENOUS PLANTS IN COMPARISON WITH SYNTHETIC INSECTICIDE FOR THE MANAGMENENT OF THRIPS Scirtothrips dorsalis (Thysnaoptera; Thripidae) IN TOMATO CROP
}

\author{
Hina Gul ${ }^{1,}$ Amjad Usman ${ }^{1 *}$, Karishma ${ }^{1}$ and Seema Zubair ${ }^{2}$
}

\begin{abstract}
Insecticidal evaluation of aqueous extracts of indigenous plant extracts in comparison with synthetic insecticide against Thrips (Scirotothrips dorsalis) on tomato was conducted under natural field condition during spring 2019. Experiment consisted of 8 treatments (neem extract, tobacco extract, garlic extract, datura extract, lantana extract, eucalyptus extract, flonicamid (synthetic insecticide) and control followed RCB Design with 3 replications. Treatments were applied thrice after 15 days interval. Results revealed that the three times application of the tested treatments showed varying toxicity against $S$. dorsalis 24, 48, 72 hours and 7 days after spray applications while ladybird beetle and green lacewing were also significantly affected when recorded 7 days after spray application. However, Flonicamid 50\%WG proved to be the most effective till $7^{\text {th }}$ and had lowest pest population followed datura and neem extract. neem extract in all the three spray application. Garlic and eucalyptus also produced significant results compared to control. Neem, tobacco, datura and flonicamid were found comparatively more hazardous to ladybird beetle and green lacewing population compared to eucalyptus, garlic and lantana to in all three spray application. Tomato yield was highest with flonicamid $(12533 \mathrm{~kg} / \mathrm{ha})$ followed by datura and neem (11810 kg/ha and $11300 \mathrm{~kg} / \mathrm{ha}$ ) respectively, while lowest $(8133 \mathrm{~kg} / \mathrm{ha})$ in control. It is concluded from the current research that flonicamid performed better against $S$. dorsalis but comparatively more hazardous to natural enemies however lantana, garlic and eucalyptus extract showed better result against $S$. dorsalis and comparatively safe towards natural enemies thus recommended to be incorporated in IPM program.
\end{abstract}

Keywords: Scirotothrips dorsalis infestation, Botanical extracts, Synthetic insecticide

Citation: Gul , H.; A. Usman; Karishma and S. Zubair. 2021. Insecticidal Evaluation Of Aqueous Extract Of Indigenous Plants In Comparison With Synthetic Insecticide For The Managmenent Of Thrips Scirtothrips Dorsalis (Thysnaoptera; Thripidae) In Tomato Crop. Pak. J. Weed Sci. Res., 27 (3):431-441

\footnotetext{
${ }^{1}$ Department of Entomology, The University of Agriculture, Peshawar

${ }^{2}$ Department Maths, Statistics and Computer Science, The University of Agriculture, Peshawar

Corresponding Email: amjadusman@aup.edu.pk
} 


\section{INTRODUCTION}

Insect pests and diseases are among the most limiting factors that hampered tomato yield (Charles and Harris, 1972). Tomato crop is attacked by number of insect pest including whitefly, thrips, and aphids, cut worm and tomato fruit worm at various stages of plant growth (Sri et al., 2017).

Among the insect pest attacking tomato crop, thrips (Thysanoptera; Thripidea) is an important polyphagus sucking pest of tomato. Besides tomato, cotton, chilli, onion, garlic are also the favorite host of thrips in Pakistan (Retiz and Tallahassee, 2009; Diaz et al., 2011). Thrips both at nymphal and adult stage cause direct damage to the host plant by sucking the cell sap. In case of sever infestation, the plant become wilt and causes complete failure of crop. Besides the direct damages, it also served as a vector of many plant viral diseases such as capsicum chlorosis and scape blight of onion (Mumfort et al., 1996; Ullman et al., 1997; Jones, 2005).

Once tomato plants become infected by viral pathogen it is difficult to control so the management strategy should be focused on vector rather than disease management. Use of pesticide is the most common control practice by the farmer for instant pest control (Noonari, 2016). Furthermore, pesticide causes several health and environment problems. The most alarming is the decline of natural enemies. Thus attention should be focused to search out alternative control measure that not only reduce pest infestation but is friendly to environment, human, natural enemies and plants itself. Use of plant extract is one of the best alternatives to toxic chemical as they are safe to human, environment and natural enemies. Effectiveness of various indigenous plants like Neem, garlic, tobacco, eucalyptus, lantana and datura have also have been reported earlier to manage sucking insect pest in different crops (Mohamed and Khalid, 2011). Flonicamid is a systematic insecticide it disrupt insect chordotonal organs that can affect hearing, balance and movement to cause cessation of feeding. It exhibits excellent performance for control of almost all sucking insects specially aphids, whiteflies and thrips by their rapid feeding inhibition effect in variety of crops and has better action through ingestion than by contact. Flonicamid has little negative impact on pollinating insects and natural enemies and thus flonicamid will provide a new option for integrated pest management programs. (Roditakis et al. 2014).

In Pakistan, limited work on Thrips (S. dorsalis) in tomato crop has been reported so the present study is an attempt to find out the most effective botanical as alternative to conventional insecticide for the sustainable management of $S$. dorsalis in tomato.

\section{MATERIAL AND METHODS}

Insecticidal evaluation of aqueous extract of indigenous plants in comparison with synthetic insecticide for the management of $S$. dorsalis in tomato crop was carried at Horticulture Farm, The University of Agriculture Peshawar, in spring 2019. Seeds of tomato hybrid Galaxy F1 were purchased from local market and sown in pots for nursery raising in $2^{\text {nd }}$ week of February and covered with plastic sheet to protect them from severe cold. Healthy tomato seedlings (about 3-4" tall) were transplanted on ridges in separate plots, each measuring $5.5 \times 2.5 \mathrm{~m}$. Plants were spaced $45 \mathrm{~cm}$ apart and there was $90 \mathrm{~cm}$ distance between rows. The experiment was laid out in Randomized Complete Block Design with three replications. Standard agronomic practices were performed uniformly in all experiment units. Leaves of the selected plants (Datura, eucalyptus, Lantana, tobacco) were collected and washed with tape water dried in shady place. The dried leaves were then grinded to get powder form. Known weights (2gram) of the each tested samples including garlic were soaked overnight in 1 liter of water. The 
extracts were than sieved to get the extract ready for treatment application. Experiment consist of 7 treatments including control Viz. Datura leaves extract $2 \%$, eucalyptus leaves extract $2 \%$, garlic bulb extract $2 \%$, Lantana leaves extract $2 \%$, Tobacco leaves extracts $2 \%$, Flonicamid 50\%WG (Synthetic insecticide) and Control. Treatments were applied thrice through Knapsack sprayers at 15 days interval in their assigned plots except control which was left untreated. S. dorsalis density were estimated on randomly selected 5 plants in each experimental plot 24 hours before spray application then after 24, 48, 72 and 7 days interval while data on insect predators (ladybird beetle and green lacewing) were recorded 24 hours before and then after 7 days of each spray applications. Tomato yield of each plot were recorded by using electric balance. Total yield was determined by adding yield of all picking then converted to $\mathrm{kg} \mathrm{ha}^{-1}$

Data recorded on all parameters was subjected to ANOVA by using software Statistics 8.1. Means was separated using LSD test at $P(0.05)$.

\section{RESULTS}

\section{S. dorsalis population plant ${ }^{-1}$}

The analysis of variance showed that tested treatments against $S$. dorsalis varied significantly $(P<0.05)$ over control after $1^{\text {st }}$ spray at 24 hours $(F=21.80 ; P=$ $0.000), 48$ hours $(F=30.33 ; P=0.000), 72$ hours $(\mathrm{F}=22.28 ; \mathrm{P}=0.000) ; 7$ days $(F=13.49 ; P=0.000)$ and non-significant $(P>0.05) \quad$ when monitored for pretreatment $(F=0.13, P=0.9948)$.

Results in Table 1 showed that all the tested treatments significantly effective throughout the observational period of one week after $1^{\text {st }}$ spray against S. dorsalis in tomato crop. Application of flonicamid 50\% WG resulted in lowest $S$. dorsalis population 1.20, 1.53, 1.73 and 3.80 plant $^{-1}$ followed by datura (1.66, $2.06,2.93$ and 4,53 plant $^{-1}$ ), neem (2.00, 2.66, 3.20 and 5.20 plant $^{-1}$ ) after 24,48 ,
72 and 7 days respectively. While eucalyptus was found least effective had $3.13,4.40,4.93$ and 8.26 S. dorsalis population plant $^{-1}$ which was found to be at par with garlic extract at 24 and 48 hours, garlic and lantana at 72 hours, garlic and control at 7 days after $1^{\text {st }}$ spray application.

It was also found that $2^{\text {nd }}$ spray application significantly affected $S$. dorsalis population $(\mathrm{P}<0.05)$ after 24 hours of second spray $(F=41.22 ; P=$ $0.000), 48$ hours of spray application $(F=45.23 ; P=0.000), 72$ hours of spray application $(\mathrm{F}=44.68 ; \mathrm{P}=0.000) ; 7$ days of spray $(F=11.47 ; P=0.0001)$. Uala $50 \%$ WG found to be the most effective had lowest $S$. dorsalis population $0.80,0.66$, 0.60 and 1.66 plant $^{-1}$ followed by datura $\left(2.06,1.80,2.20\right.$ and 4.66 plant $\left.^{-1}\right)$, neem $\left(2.80,1.93,2.53\right.$ and 5.66 plant $\left.^{-1}\right)$ after $24,48,72$ and 7 days respectively. While eucalyptus was found least effective had $7.66,4.66,5.13$ and 7.53 S. dorsalis population plant ${ }^{-1}$ which was found to be at par with garlic at 24 and 48 hours, garlic and lantana at 72 hours, garlic and control at 7 days after $2^{\text {nd }}$ spray application.

Similarly $S$. dorsalis population was significantly affected by $3^{\text {rd }}$ spray application when observed after 24, 48, 72,7 days $(F=54.28 ; P=0.000)$, $(F=56.71 ; \quad P=0.000),(F=105.82$; $\mathrm{P}=0.000)$ and $(\mathrm{F}=231.53 ; \mathrm{P}=0.000)$ respectively. Again application of flonicamid $50 \%$ WG resulted in lowest $S$. dorsalis population $0.50,0.23,0.11$ and 0.00 plant $^{-1}$ followed by datura (1.30, $1.03,1.00$ and 1.26 plant $^{-1}$ ), neem (2.56, $1.56,1.43$ and 1.90 plant $^{-1}$ ) after 24,48 , 72 and 7 days respectively. While eucalyptus was found least effective had $6.16,4.16,4.23$ and 4.76 S. dorsalis population plant $^{-1}$ which was found to be at par with garlic at 24 and 48 hours, garlic and lantana at 72 hours, garlic and control at 7 days after $1^{\text {st }}$ spray application.

\section{Ladybird beetle plant ${ }^{-1}$}


Pre spray data of $1^{\text {st }}$ spray and $2^{\text {nd }}$ spray was non-significant ranging from ( 1.37 to 1.84 plant $^{-1}$ ) and (1.33 to 1.79 plant $^{-1}$ ) respectively. While ladybird beetle population was significantly different before $3^{\text {rd }}$ spray application ranging from (0.46 to 1.40 plant $^{-1}$ ). Ladybird beetle population was significantly affected by treatments application when compared with control. Neem extract was found to be more hazardous resulting in maximum reduction(89.40, 90.96 and $79.7 \%$ ) of ladybird beetle after $1^{\text {st }}, 2^{\text {nd }}$ and $3^{\text {rd }}$ spray application followed by tobacco and datura with $\%$ reduction of $(86.93,87.86$ and $69.62 \%)$ and $(87.50,91.06$ and $71.42 \%)$ respectively. Whereas eucalyptus and lantana were comparatively less hazardous in all three sprays application resulted in the minimum reduction of 46.31-67.76\% (Table 2).

Table No. 1. S. dorsalis density on tomato crop before and after $1^{\text {st }}, 2^{\text {nd }}$ and $3^{\text {rd }}$ spray application of different botanical extracts and synthetic insecticide during 2019

\begin{tabular}{|c|c|c|c|c|c|}
\hline \multirow[t]{3}{*}{ Treatments } & \multicolumn{5}{|c|}{ S. dorsalis plant ${ }^{-1}$} \\
\hline & \multirow{2}{*}{$\begin{array}{l}\text { Before spray } \\
\text { application }\end{array}$} & \multicolumn{4}{|c|}{ After spray application } \\
\hline & & 24 hours & 48 hours & 72 hours & 7days \\
\hline Datura $2 \%$ & $3.63 \mathrm{a}$ & $1.66 \mathrm{ef}$ & $2.06 \mathrm{fg}$ & $2.93 \mathrm{e}$ & $4.53 \mathrm{e}$ \\
\hline $\begin{array}{l}\text { Eucalyptus } \\
2 \%\end{array}$ & 3.76 a & $3.13 \mathrm{~b}$ & $4.40 \mathrm{~b}$ & $4.93 \mathrm{~b}$ & $8.26 a b$ \\
\hline Garlic 2\% & $3.86 \mathrm{a}$ & $2.66 \mathrm{bc}$ & $4.00 \mathrm{bc}$ & $4.53 \mathrm{bc}$ & $6.33 \mathrm{~cd}$ \\
\hline Lantana $2 \%$ & $3.66 \mathrm{a}$ & $2.40 \mathrm{~cd}$ & $3.46 \mathrm{~cd}$ & $4.20 \mathrm{bc}$ & $6.80 \mathrm{bc}$ \\
\hline Neem $2 \%$ & $3.60 \mathrm{a}$ & $2.00 \mathrm{de}$ & 2.66 ef & $3.20 \mathrm{de}$ & $5.20 \mathrm{de}$ \\
\hline $\begin{array}{l}\text { Flonicamid } \\
50 \% \text { WG }\end{array}$ & $3.93 \mathrm{a}$ & $1.20 \mathrm{f}$ & $1.53 \mathrm{~g}$ & $1.73 \mathrm{f}$ & $3.80 \mathrm{e}$ \\
\hline Tobacco $2 \%$ & $3.80 \mathrm{a}$ & $2.06 \mathrm{de}$ & $3.00 \mathrm{de}$ & $3.86 \mathrm{~cd}$ & $6.20 \mathrm{~cd}$ \\
\hline Control & $3.83 \mathrm{a}$ & $3.80 \mathrm{a}$ & $5.13 \mathrm{a}$ & $5.80 \mathrm{a}$ & $9.40 \mathrm{a}$ \\
\hline \multicolumn{6}{|l|}{$2^{\text {nd }}$ Spray } \\
\hline Datura $2 \%$ & $5.33 \mathrm{~d}$ & $2.06 \mathrm{de}$ & 1.80 ef & $2.20 \mathrm{e}$ & $4.66 \mathrm{c}$ \\
\hline $\begin{array}{l}\text { Eucalyptus } \\
2 \%\end{array}$ & $8.26 b$ & $7.66 a b$ & $4.66 \mathrm{~b}$ & $5.13 b$ & $7.53 b$ \\
\hline Garlic 2\% & $8.13 b$ & $6.40 \mathrm{~b}$ & $4.06 \mathrm{bc}$ & $4.53 \mathrm{bc}$ & $7.00 \mathrm{~b}$ \\
\hline Lantana $2 \%$ & $7.53 \mathrm{bc}$ & $3.53 \mathrm{c}$ & $3.33 \mathrm{~cd}$ & $3.93 \mathrm{~cd}$ & $6.40 \mathrm{bc}$ \\
\hline Neem $2 \%$ & $6.06 \mathrm{~cd}$ & $2.80 \mathrm{~cd}$ & $1.93 \mathrm{e}$ & $2.53 \mathrm{e}$ & $5.66 \mathrm{bc}$ \\
\hline $\begin{array}{l}\text { Flonicamid } \\
50 \% \text { WG }\end{array}$ & $3.33 \mathrm{e}$ & $0.80 \mathrm{e}$ & $0.66 \mathrm{f}$ & $0.60 \mathrm{f}$ & $1.66 \mathrm{~d}$ \\
\hline Tobacco $2 \%$ & $6.93 \mathrm{bc}$ & $3.66 \mathrm{c}$ & $2.60 \mathrm{de}$ & $3.20 \mathrm{de}$ & $6.13 b c$ \\
\hline Control & $9.80 \mathrm{a}$ & $9.00 \mathrm{a}$ & $8.20 \mathrm{a}$ & $8.00 \mathrm{a}$ & $11.66 \mathrm{a}$ \\
\hline \multicolumn{6}{|l|}{$3^{\text {rd }}$ Spray } \\
\hline Datura $2 \%$ & $3.66 \mathrm{c}$ & $1.30 \mathrm{e}$ & 1.03 ef & $1.00 \mathrm{~d}$ & $1.26 \mathrm{f}$ \\
\hline
\end{tabular}




$\begin{array}{lccccc}\text { Eucalyptus } & 6.60 \mathrm{ab} & 6.16 \mathrm{~b} & 4.16 \mathrm{~b} & 4.23 \mathrm{~b} & 4.76 \mathrm{a} \\ 2 \% & & & & & \\ \text { Garlic 2\% } & 6.26 \mathrm{~b} & 3.56 \mathrm{~cd} & 3.63 \mathrm{bc} & 3.36 \mathrm{c} & 3.83 \mathrm{c} \\ \text { Lantana 2\% } & 6.06 \mathrm{~b} & 3.83 \mathrm{c} & 3.30 \mathrm{e} & 2.70 \mathrm{c} & 2.80 \mathrm{~d} \\ \text { Neem 2\% } & 4.93 \mathrm{bc} & 2.56 \mathrm{~d} & 1.56 \mathrm{de} & 1.43 \mathrm{~d} & 1.90 \mathrm{e} \\ \text { Flonicamid } & 1.56 \mathrm{~d} & 0.50 \mathrm{e} & 0.23 \mathrm{ef} & 0.11 \mathrm{e} & 0.00 \mathrm{~g} \\ 50 \% \text { WG } & & & & & 1.93 \mathrm{e} \\ \text { Tobacco 2\% } & 5.40 \mathrm{bc} & 2.63 \mathrm{~d} & 2.23 \mathrm{~d} & 1.50 \mathrm{~d} & 7.70 \mathrm{a} \\ \text { Control } & 8.13 \mathrm{a} & 9.00 \mathrm{a} & 6.76 \mathrm{a} & 7.56 \mathrm{a} & \end{array}$

Means with different letters are significantly different at p 0.05 using LSD test

Table No. 2. Ladybird beetle population on tomato crop before and after spray application of different botanical extracts and synthetic insecticide during 2019.

\section{Lady bird beetle plant ${ }^{-1}$}

\begin{tabular}{|c|c|c|c|c|c|c|}
\hline \multirow[t]{2}{*}{ Treatments } & \multicolumn{2}{|c|}{$1^{\text {st }}$ Spray } & \multicolumn{2}{|c|}{$2^{\text {nd }}$ spray } & \multicolumn{2}{|c|}{$3^{\text {rd }}$ spray } \\
\hline & Before & After & Before & After & Before & After \\
\hline Datura 2\% & $1.76 \mathrm{a}$ & $\begin{array}{l}0.23 \\
d\end{array}$ & $1.73 \mathrm{a}$ & $0.21 \mathrm{e}$ & $\begin{array}{l}0.79 \\
b c\end{array}$ & $\begin{array}{l}0.24 \\
d\end{array}$ \\
\hline Eucalyptus 2\% & $1.67 \mathrm{a}$ & $\begin{array}{l}0.56 \\
b\end{array}$ & $1.37 \mathrm{a}$ & $0.39 \mathrm{c}$ & $0.95 \mathrm{~b}$ & $\begin{array}{l}0.51 \\
b\end{array}$ \\
\hline Garlic 2\% & $1.75 \mathrm{a}$ & $\begin{array}{l}0.31 \\
\mathrm{C}\end{array}$ & $1.54 \mathrm{a}$ & $0.33 \mathrm{~d}$ & $0.96 \mathrm{~b}$ & $\begin{array}{l}0.33 \\
c\end{array}$ \\
\hline Lantana $2 \%$ & $1.45 \mathrm{a}$ & $\begin{array}{l}0.49 \\
\mathrm{~b}\end{array}$ & $1.52 \mathrm{a}$ & $0.49 \mathrm{~b}$ & $\begin{array}{l}1.00 \\
b\end{array}$ & $\begin{array}{l}0.38 \\
\mathrm{C}\end{array}$ \\
\hline Neem 2\% & $1.51 \mathrm{a}$ & $\begin{array}{l}0.16 \\
d\end{array}$ & $1.66 \mathrm{a}$ & $0.15 \mathrm{f}$ & $0.74 \mathrm{c}$ & $\begin{array}{l}0.15 \\
d\end{array}$ \\
\hline $\begin{array}{l}\text { Flonicamid } 50 \% \\
\text { WG }\end{array}$ & $1.37 \mathrm{a}$ & $\begin{array}{l}0.34 \\
\mathrm{C}\end{array}$ & $1.46 \mathrm{a}$ & $\begin{array}{l}0.20 \\
\text { ef }\end{array}$ & $0.46 \mathrm{~d}$ & $\begin{array}{l}0.27 \\
d\end{array}$ \\
\hline Tobacco 2\% & $1.84 \mathrm{a}$ & $\begin{array}{l}0.23 \\
d\end{array}$ & $1.79 \mathrm{a}$ & $\begin{array}{l}0.16 \\
\text { ef }\end{array}$ & $\begin{array}{l}0.84 \\
\mathrm{bc}\end{array}$ & $\begin{array}{l}0.24 \\
d\end{array}$ \\
\hline Control & $1.46 \mathrm{a}$ & $\begin{array}{l}0.71 \\
a\end{array}$ & $1.33 \mathrm{a}$ & $0.64 a$ & $1.40 \mathrm{a}$ & $\begin{array}{l}0.65 \\
a\end{array}$ \\
\hline LSD $_{(0.05)}$ & 0.556 & 0.075 & 0.500 & 0.058 & 0.222 & 0.062 \\
\hline
\end{tabular}

Means with different letters are significantly different at $\mathrm{p} 0.05$ using LSD test 
Green lacewing population plant ${ }^{-1}$

As presented in Table 3. Green lacewing population was significantly affected by all the tested treatments when compared to control in all three spray application. Flonicamid was found to be more hazardous had maximum reduction ranging from $75-88.77 \%$ in green lacewing population in all three spray application. Where as lantana and tobacco were found to be less hazardous to green lacewing with \% reduction ranging from 7.5 to 41.93 .

Table 3. Green lacewing before and after spray application of different botanical extracts and synthetic insecticide on tomato crop during 2019.

\begin{tabular}{|c|c|c|c|c|c|c|}
\hline \multirow[t]{3}{*}{ Treatments } & \multicolumn{6}{|c|}{ Green lace wing plant $^{-1}$} \\
\hline & \multicolumn{2}{|r|}{$1^{\text {st }}$ spray } & \multicolumn{2}{|c|}{$2^{\text {nd }}$ spray } & \multicolumn{2}{|c|}{$3^{\text {rd }}$ spray } \\
\hline & Before & After & Before & After & Before & After \\
\hline Datura $2 \%$ & $0.86 \mathrm{ab}$ & $0.77 \mathrm{~b}$ & $1.87 \mathrm{ab}$ & $0.53 \mathrm{~d}$ & $0.86 \mathrm{ab}$ & $\begin{array}{c}0.26 \\
\mathrm{de}\end{array}$ \\
\hline Eucalyptus 2\% & $0.93 a b$ & $0.69 \mathrm{~b}$ & $1.77 \mathrm{ab}$ & $0.87 b$ & $0.92 a$ & $0.43 c$ \\
\hline Garlic 2\% & $0.86 a b$ & $0.51 \mathrm{c}$ & $1.85 \mathrm{ab}$ & $0.70 \mathrm{c}$ & $0.79 \mathrm{ab}$ & $0.31 d$ \\
\hline Lantana $2 \%$ & $0.80 \mathrm{~b}$ & $0.74 b$ & $1.79 \mathrm{ab}$ & $0.92 b$ & $0.73 \mathrm{bc}$ & $0.51 b$ \\
\hline Neem 2\% & $0.87 a b$ & $0.39 \mathrm{~d}$ & $1.52 b$ & $0.49 \mathrm{~d}$ & $0.59 \mathrm{~cd}$ & $0.21 \mathrm{e}$ \\
\hline $\begin{array}{l}\text { Flonicamid } \\
\text { WG }\end{array}$ & $0.98 a$ & $0.11 \mathrm{e}$ & $0.32 \mathrm{~d}$ & $\begin{array}{c}0.08 \\
\mathrm{e}\end{array}$ & $0.47 \mathrm{~d}$ & $0.10 \mathrm{f}$ \\
\hline Tobacco $2 \%$ & $0.93 a b$ & $0.73 b$ & $0.93 \mathrm{c}$ & $0.54 \mathrm{~d}$ & $0.73 \mathrm{bc}$ & $0.23 \mathrm{e}$ \\
\hline Control & $0.98 a$ & $1.11 \mathrm{a}$ & $1.99 \mathrm{a}$ & $2.11 \mathrm{a}$ & $0.93 a$ & $0.63 a$ \\
\hline LSD $_{(0.05)}$ & 0.166 & 0.084 & 0.374 & 0.119 & 0.156 & 0.060 \\
\hline
\end{tabular}

Means with different letters are significantly different at p 0.05 using LSD test

\section{Yield}

Significantly highest yield was achieved in Flonicamid 50\%WG treated plot (12533 $\left.\mathrm{kg} \mathrm{ha}{ }^{-1}\right)$ followed by plot treated with datura (11810 kg ha-1) and neem (11300 $\left.\mathrm{kg} \mathrm{ha}^{-1}\right)$. While lowest tomato yield (8133 $\mathrm{kg} \mathrm{ha}^{-1}$ ) was obtained in the control. Yield obtained in Eucalyptus (10000 kg ha ${ }^{-1}$ ) was at par with garlic (10167 $\mathrm{kg} \mathrm{ha}^{-1}$ and lantana (10267 kg ha-1) (Table 4). 
Table No.4 Effect of different botanicals extracts and synthetic insecticide on tomato yield crop during 2019

\begin{tabular}{lc}
\hline Treatments & Yield ( kgha $\left.{ }^{-1}\right)$ \\
\hline Datura 2\% & $11810 \mathrm{ab}$ \\
Eucalyptus 2\% & $10000 \mathrm{c}$ \\
Garlic 2\% & $10167 \mathrm{c}$ \\
Lantana 2\% & $10267 \mathrm{c}$ \\
Neem 2\% & $11300 \mathrm{a}-\mathrm{c}$ \\
Flonicamid 50\% WG & $12533 \mathrm{a}$ \\
Tobacco 2\% & $10800 \mathrm{bc}$ \\
Control & $8133 \mathrm{~d}$
\end{tabular}

LSD (0.05)

1408

Means with different letters are significantly different at $\mathrm{p} 0.05$ using LSD test

\section{DISCUSSION}

In the present study six botanicals (neem, datura, tobacco, lantana, garlic and eucalyptus) were tested in comparison with synthetic insecticide (Flonicamid) against $S$. dorsalis in tomato. All the tested treatments datura extract, neem extract, garlic extract, tobacco extract, lantana extract, eucalyptus extract and synthetic insecticide (flonicamid) were found better than control in reducing $S$. dorsalis density. Some earlier researchers Oparacke et al. (2006), Shah et al. (2005), Kuganathan, et al. (2008). Singh et al. (2014) and Din et al. (2016) has also indicated the effectiveness and insecticidal potential of neem, tobacco, garlic, lantana and eucalyptus used alone or in combination against various insects.

Present study showed that insecticide flonicamid found better that significantly reduced $S$. dorsalis infestation up to7 days. Present finding are also supported by Golmohammadi and Mohammadipour (2015) that synthetic insecticide Flonicamid performed better in comparison with botanicals. The better performance of flonicamid against $S$. dorsalis population could be due to its systemic, rapid and knock down effect as compared to botanicals. Among botanicals, datura, neem and tobacco extract efficiently suppressed $S$. dorsalis infestation in all the three spray applications. Liyanage et al. (2009) also found neem extract at par with datura extract against different sucking insect pests under laboratory conditions. Khaliq, et al. ( 2014) reported $60 \%$ reduction in thrips population up to 7 days by spraying datura, neem and bitter apple. Similarly Aalew (2005) found that the ethanol extracts of neem seed also remained effective against thrips under field condition. In the present study garlic, lantana and eucalyptus were found least effective in suppressing thrips infestation when compared with other botanicals and synthetic insecticide. Similar results were also reported by Khan et (2013) that garlic extracts was the most effective against other sucking insect but least effective against thrips in cotton.

Observation on natural enemies showed the presence of two insect predators (ladybird beetle and green lace wing) in tomato field. Usman et al. (2018) also reported the presence of ladybird beetle 
and green lace wing in tomato. Challan (1943), Higgins (1992), Messelink et al. (2008), Synder et al. (2004) and Karuppuchamy (2016) reported predatory mites, minute pirate bugs, ladybird beetle, green lacewing, Dasyscapus paravipennis, $F$. vespiformis and chrysopids as natural enemies of thrips. While Smith and Chaney (2007) and Hameed et al. (2013) reported only syrphid fly, a predator of sucking insect pest thrips, whiteflies and aphids. Variation in the presence of natural enemies could be due to difference in the ecological condition and the presence of alternate crop. In this study, reductions in ladybird beetle and green lace wing populations were observed. This shows that all the tested treatments were not completely safe but comparatively a little bit harmful to lady bird beetle and green lacewing when compared with control. Eucalyptus, lantna and garlic extract were found to be comparatively safer while Neem, Tobacco, Datura and Flonicamid a synthetic insecticide were found to be comparatively harmful to both the predators. Dodia et al. (2008) reported that nicotine is not selective insecticide and is highly toxic to a range of species including predatory insects. Diraviam and Viraktamath (1993) mentioned nicotine is a safer insecticide for higher animals and safer to Curinus coeruleus and other predators. Saxena (1987)reported that neem is harmless to ladybird beetles that consume aphids and wasps that act as parasites on various crop pests. Some contrary results have also been reported by Rao et al. (2007), Khan et al. (2013) reported that datura and neem are ecofriendly and have no effect on natural enemies of $S$. dorsalis. Toxicity may depend on the predator species used. However, it needs further studies to confirm the effectiveness of theses botanicals in lab conditions. Hoelmer et al. (1990) discovered that a commercial neem insecticide was not toxic to adult coccinellid predators. Azadirachtin was virtually nontoxic to larvae of $C$. septempunctata (seven-spot ladybird) exposed to direct sprays in the laboratory (Banken and Stark, 1997). Jones et al. (2005) observed that bacteria and neem based insecticides were harm less to natural predatory fauna. However, Tunca et al. (2012) commented that no pesticide is $100 \%$ safe and non toxic to natural enemies. Nevertheless, the margin of safety for botanical pesticides is generally much higher than synthetic chemical pesticides. The results of the present study are in agreement with those of Tunca et al. (2012) reporting that new chemistry insecticides and botanicals are relatively safe for natural predators.

Tomato yield was significantly higher in plots treated with botanicals as well as synthetic insecticide compared to control. Results also showed that plants with higher thrips density gave the lower yield and vice versa. The nature of damage of thrips that affects photosynthesis process resulting in affecting the tomato yield might be one of the reasons for low yield.

\section{CONCLUSION AND RECOMMENDATIONS}

It was concluded that synthetic insecticide and all the tested botanical extracts have the potential to control S. dorsalis and enhanced tomato yield. Although Flonicamid $50 \%$ WG control the target pest but significantly reduced the population of beneficial insects. However, botanicals datura, eucalyptus, tobacco and lantana found to be less hazardous to the beneficial insects than synthetic insecticide would fit well in IPM practice as one of the insecticidal component for sustainable management of $S$. dorsalis. 


\section{REFERENCES}

Ali, S. S., S. Ahmad, S. S. Ahmed, H. Rizwana, S. Siddiqui, S. S. Ali, I. A. Rattar and M.A. Shah. 2016. Effect of biopesticides against sucking insect pests of Brinjal crop under field conditions. J. Basic and Appl. Sci.,12 41-49.

Ayalew, G. 2005. Comparison among some botanicals and synthetic insecticides for the control of onion thrips, (Thrips tabaci, Lind.) (Thysanoptera: Thripidae) Proceedings of the 13th Annual Conference of the Crop Protection Society of Ethiopia (CPSE), Addis Ababa, Ethiopia.

Challan, M. E. 1943. Natural enemies of the cacao. Bull Entomol Res. 34(4): 313-321.

Charles, W. B. and R. E. Harris. 1972. Tomato fruit-set at high and low temperature. Candian J. Pl. Sci. 52:497-506.

Diaz, M. J., M. Fuchs, B. A. Nault, J. Fail and A. M. Shelton. 2011. Onion thrips (Thysanoptera:Thripidae): A global pest of increasing concern in onion. J. Econ. Entomol. 104(1): 1-13.

Din, N., M. Ashraf and S. Hussain. 2016. Effect of different non- chemical and chemical measure against onion thrips. J. Entomol.Zool. Studies. 4(5): 10-12.

Diraviam, C. and A. Virktamath. 1993. Onion thrips and its control measures. J. Entomol. 18: 77-79.

Dodia, D.A.,I.S. Pate and G.M. Patel. 2008. Botanical pesticides for Pest Management, pp 354.

Golmohammadi, G. and A. Mohammadipour. 2015. Efficacy of herbal extract and synthetic compounds against strawberry thrips, Frankliniellaoccidentalis (Pregande) under greenhouse condition. J. Entomol. Zool. Studies. 3: 42-44.

Hameed, A., F. H. Shah, M. A. Mehmood, H. Karar, B. Siddiuque, S. K. Nabi, A. Amin, A. M. Pasha and Z. Khaliq. 2013. Comparative efficacy of five
Medicinal plant extract against Rosa indica insect pests and elaboration of hazardous effect on pollinators and predators. Pak. Entomol. 35(2): 145150.

Higgins, J. C. 1992. Western flower Thrips (Thysanoptera:Thripidae) in greenhouse : population dynamics, distribution on plant and association with predators. J. Econ. Entomol. 85(5): 1891-1903.

Jone, R. D. 2005. Plant viruses transmitted by thrips. European J. PI. Pathol. 113(2): 119-157.

Karuppuchamy, P. 2016. Ecologically sustainable pest management for thrips and aphids in groundnut. Madras Agric. J. 103 (4-6): 141-145.

Khan, A. A., M. Afzal, A. M. Raza, A. M. Khan, J. Iqbal, H. M. Tahir, J. A. Qureshi, A. Khaliq, M. Zia-ul-Haq and M. A. Aqeel. 2013. Toxicity of botanicals and selective insecticide to Citrus psylla, Diaphorina citri $\mathrm{K}$. (Hompotera: Psyllidae) in laboratory condition. Jokull J., 63(8): 780-784.

Khan, M.A. and S. Atta. 2007. Effect of imidacloprid and extracts of neem and dathura on white fly population and tomato yellow leaf curl virus disease incidence Proceeding of the International Symposium on Microbial Technologies for Sustainable Agriculture, Faisalabad, Pakistan.74 pp.

Kuganathan, N., S. Saminathan and S. Muttukrishna. 2008. Toxicity of Datura alba leaf extract to aphids and ants. J. Toxicol. 5(2): 151-156.

Liyanage, N.J., R. Chauhan and R. Singh. 2009. Effect of methanolic leaf extract and fractions of Datura metel on oviposition behavior of spotted bollworm of cotton. J. Cotton Res. Dev., 23(2): 270-274.

Messelink, J. G., R. V. Maanen, S. E. V. Steenpaal and A. Janssen. 2008. Biological control of thrips and whiteflies by a shared predator: two pests are better than one. Bio Control. 44(3): 372-379. 
Mohamed, E. S. I. and S. Khalid. 2011. Note on effect of pheromone trapping of the tomato leaf miner, Tuta absoluta (Meyrick) (Lepidoptera:Gelechiidae) in Sudan the 85 meeting of National Pest and Diseases Committee, Agricultural Research Corporation, Wad Medanii, Sudan,9 pp.

Mumfort, R. A., I. Barker and K. R. Wood. 1996. The biology of the tospoviruses. Annals of Appl. Biol. 128:159-183.

Noonari, M. A., G. H. Abro, R. D. Khuhro and A. S.Buriro. 2016. Efficacy of biopesticide for management of sucking insect pests of cotton, Gossipium hirstum. J. Basic and Appl. Sci. 12:306-313.

Oparacke, A. M., M. Dike and C. Amatubi. 2006. Botanical pesticide mixture for insect pest management on cowpea, Vigna uriguiculata (L.) walp plant- The legume flower but thrips, Megalorothrips sjosledti Trybom. J. Sustainable Agric. 29 (1): 5- 13.

Rao, R. V. G., V. Visalakshmi, M. Suganthy and B. V. Reddy. 2007. Relative toxicity of neem to natural enemies associated with the check pea ecosystem: a case study. Int. J. Tropical Insect Sci. 27(3-4):229-235.

Retiz, R. S. and M. Tallahassee. 2009. Biology and ecology of the western flower thrips (Tysanoptera: Thripidae): The making of pest. Florida Entomol. 92(1):7-13.

Rodatikas, E., N. Fytrou, M. Staurakaki, J, Vontas and A. Tsagkarakou. 2014. Activity of flonicamid on the sweet potato white fly Bemisa tabaci and its natural enemies. Pest Manag. Sci. 70: 460-467.

Saxena, R.C., 1987. Insecticides from plants. In: Eds. Amaan JT, Philogene BJR, Morand P, ACS Symposium Series, India

Shah, S. A. M., H. C. Singh and R. Varatharajan. 2005. Effect of neem on onion thrips, Thrips tabaci. Annals PI. Protec. Sci. 13(2): 470-471.

Singh D, T. Verma, S. Aswal and G. Aswani. 2014. Effect of different botanical pesticide against Thrips tabaci on garlic crop. Asian Agric. History. 18(10): 57-61.

Smith, A. H. and W. E. Chaney. 2007. A survey of syophid predators of Nasonovia ribisnigri in organic Lettuce on the central coast of California. J. Economic Entomol. 100(1): 39-48.

Solangi. B. K., F. N. Khoso, M. A. Shafique, A. M. Ahmed, A. A. Gilal, M.M.A.Talpur and K. H. Dhiloo. 2017. Host plant preference of sucking pest complex to different tomato genotypes. J. Entomol. Zool. Studies. 5(1): 293-297.

Sri, R. N., S. Jha and N. S. Latha. 2017. Insect Pests of Tomato and Their Weather Relations under Open and Cover Cultivation. Int. J. Curr. Microbiol. App. Sci. 6(9): 368-375.

Stoll, G. 2000. Natural crop protection in the Tropics: Letting information come to life. Hohberg, Germany.

Synder, E. W., S. N. Ballard, S. Yang, G. M. Clevenger, T. D. Miller, J. J. Ahn, T. D. Hatten and A. A. Berryman. 2004. Complemetary biocontrol of aphids by the ladybird beetle Harmonia axyridis and the parasitoid Aphelinus asychis on greenhouse rose. Bio.Control. 30:229-235.

Tanzubil, P. B., 1991. Control of some insect pest of cowepea (Vigna unguiculuta) with neem (Azadirachta indica A. Juss) in Nothern Ghana Int. J. Pest Manag. 37(3): 216-217.

Ullman, D. E., J. L. Sherwood and T. L. German. 1997. Thrips as vector of plant pathogens in: Lewis, $T$, eds. Thrips as crop pests CAB (Eds). International, Walling Ford, UK.539565.

Usman, A., M. I. Ali, M. Shah, F. Amin and J.Sarwar. 2018. Comparative efficacy of indigenous plant extracts and a synthetic insecticide for the management of tomato fruit worm (Helicoverpa armigera Hub.) and their effect on natural enemies in tomato crop. Pure Appl. Biol. 7(3): 10141020.

Vestergaard, S., T. M. Butt, A. T. Gillespie, G. Schreiter and J. Eilenberg. 1995. Pathogenecity of the 
hyphomycete fungi, Verticillum lecanii and $M$. anisopliae to the western flower thrips, Frankliniella occidentalis. Biocont. Sci. and Technol. 5: 185-192. 